\title{
Large-Scale Serological Survey of Caprine Arthritis-Encephalitis Virus (CAEV) in Korean Black Goats (Capra hircus aegagrus)
}

\author{
Jae-Ku OEM ${ }^{1)}$, Joon-Yee CHUNG ${ }^{1)}$, Jae-Won BYUN ${ }^{1)}$, Ha-Young KIM ${ }^{1)}$, Dongmi KWAK ${ }^{2)}$ and Byeong Yeal JUNG ${ }^{1) *}$ \\ 1) Animal Disease Diagnostic Division, Animal, Plant and Fisheries Quarantine and Inspection Agency, Anyang, Gyeonggi-do 430-757, \\ Korea \\ 2) Department of Parasitology, College of Veterinary Medicine, Kyungpook National University, Daegu 702-701, Korea
}

(Received 7 March 2012/Accepted 6 July 2012/Published online in J-STAGE 20 July 2012)

ABSTRACT. A national serological survey of caprine arthritis-encephalitis virus (CAEV) infection was conducted using an enzyme-linked immunosorbent assay (ELISA) and an agar gel immunodiffusion (AGID) test. A total of 658 black goats of various breeds were sampled from 59 farms in three regions of Korea. The CAEV-positive goats were predominantly detected in the Southern region ( $\mathrm{n}=17)$ as compared with the Northern $(n=1)$ and Central regions $(n=0)\left(\chi^{2}=6.26, P=0.044\right)$. Among 658 goats tested, 18 were positive in both ELISA and AGID, indicating a CAEV prevalence of $2.73 \%$ (95\% confidence interval: 1.74-4.28). These results indicate that CAEV is present in Korean black goats.

KEY WORDS: caprine arthritis-encephalitis virus, goat, serological survey.

doi: 10.1292/jvms.12-0103; J. Vet. Med. Sci. 74(12): 1657-1659, 2012

Caprine arthritis-encephalitis virus (CAEV) belongs to the genus lentivirus, family Retroviridae. CAEV is a persistent disease in goats characterized by polyarthritis, mastitis and pneumonia in adults and leukoencephalomyelitis in kids $[4,6]$. CAEV has been reported in most goat-rearing countries $[1,13]$. Live animal trading across national boundaries is considered an important cause of horizontal CAEV transmission, whilst ingestion of colostrums and milk represent important causes of transmission from mother to offspring $[3,4]$. In 2002, CAEV was identified in Japan [10]. Infected goats develop anti-CAEV antibodies and develop a persistent, lifelong infection. Korea was considered free from CAEV; however, CAEV RNA was detected in Korean dairy goats in 2008 [12], and an outbreak of CAEV was reported on a Korean goat farm in 2010 [14].

The period between CAEV infection and the detection of antibodies and onset of clinical signs may vary from months to years [3]. Several diagnostic techniques are used to detect CAEV infections. These are based on the detection of either antibodies or virus [9]. Virus isolation and cell culture detection techniques have been used but cannot be extensively applied, as specific cell types are replicationrestrictive to particular strains [15] and CAEV heterogeneity and low viral loads have hampered the use of the polymerase chain reaction (PCR) as a reference technique. In addition, positive PCR results have been obtained in some seronegative animals [9]. Thus, the diagnosis of infection is typically performed by serological testing [9] including enzyme-linked immunosorbent assays (ELISA), and

\footnotetext{
*Correspondence to: Jung, B. Y., Animal Disease Diagnostic Division, Animal, Plant and Fisheries Quarantine and Inspection Agency, Anyang, Gyeonggi-do 430-757, Korea. e-mail: jungby@Korea.kr

(C)2012 The Japanese Society of Veterinary Science
}

agar gel immunodiffusion (AGID) tests, with PCR used to complement serological methods. ELISA represents a more sensitive technique than AGID testing for the detection of CAEV antibodies. Western blotting, radioimmunoassay, and radioimmunoprecipitation are also used as supplementary tests to discriminate for indeterminate results obtained from screening assays.

In Korea, the black goat population contains approximately 266,000 animals distributed in 21,000 herds [11]. Approximately $55 \%$ of the total goat population lives in the Southern region. Relatively low populations have been recorded in the Northern and Central regions. Although regional serological and virological investigations in dairy goats have been performed [12], no large-scale serological survey has been reported in Korean black goats. In this study, we conducted a large-scale serological survey to investigate the CAEV status in Korean black goats. A total of 658 black goats of various breeds were sampled from 59 farms from November, 2009 to August, 2011. Only farms with 100 or more goat herds were included in the study. Approximately 10 goats were randomly selected and sampled from each farm. Serum samples were divided into three geographical regions (Northern, Central, and Southern regions). Sera were stored at $-20^{\circ} \mathrm{C}$ until screened.

The CAEV/MVV Antibody Test Kit (IDEXX, The Netherlands) based on an ELISA was used to detect CAEV-specific antibodies in serum. All serum samples were retested and confirmed by an AGID test. AGID tests were performed as recommended by the manufacturer (Veterinary Laboratory Agency, Weybridge, U. K.). ELISA and AGID results were compared for individual goats. However, none of the known methods, including ELISA, AGID and PCR, are considered a "gold standard" due to generation of false-positive and/or false-negative reactions. Thus, when the ELISA and AGID results correlated, they were considered reliable.

Chi-square analysis was used to analyze regional dif- 
ferences for herds and individual goats. A value of $P<0.05$ was considered statistically significant. The accuracies of ELISA and AGID were compared, and the agreement levels between the test results were determined by calculating the kappa values (proportion of chance-corrected test agreement). The kappa value can range between 0.0 and 1.0, with values $>0.75$ representing excellent agreement beyond chance, values between 0.4 and 0.75 indicating fair to good agreement and values $<0.4$ denoting poor agreement beyond that due to chance alone.

Among the 658 goats tested, 18 were positive in both ELISA and AGID tests, making the CAEV prevalence $2.73 \%$ (95\% confidence interval: 1.74-4.28). The numbers of goats tested by region were 138, 78 and 442 for the Northern, Central and Southern regions, respectively. The mean numbers of goats sampled per herd were $10.62( \pm 2.87), 9.75( \pm 3.63)$ and $11.65( \pm 3.29)$ for the Northern, Central and Southern regions, respectively. CAEV-positive goats were predominantly detected in the Southern region $(\mathrm{n}=17)$, as compared with the Northern $(n=1)$ and Central regions $(n=0)$. Differences in the numbers of positive goats among the regions were statistically significant $\left(\chi^{2}=6.26, P=0.044\right)$.

This study used 13, 8 and 38 herds from the Northern, Central and Southern regions, respectively. CAEV prevalence in the Southern region $(23.68 \%)$ was higher than in the Northern $(7.69 \%)$ and Central $(0 \%)$ regions $(P>0.05)$. However, these differences were not statistically significant due to the small herd numbers $\left(\chi^{2}=4.52, P=0.104\right)$.

A summary of ELISA and AGID results is shown in Table 1. Agreement between ELISA and AGID results was obtained for 636 serum samples ( $97 \%$ of total samples). The results showed that 618 serum samples were negative and 18 sera samples were positive by both tests. Discrepancies were observed in 22 serum samples (3.34\% of total samples); 17 samples were AGID-/ELISA+, and 5 samples were AGID+/ ELISA-. ELISA sensitivity and specificity were 78.4 and $97.3 \%$, respectively, whilst those of AGID were 51.4 and $99.2 \%$, respectively. These data indicate that the ELISA sensitivity exceeded that of AGID in this study. Thus, ELISA detection is useful for the identification of CAEV-infected goats under field conditions and has the potential for use in control and eradication programs in Korea.

The prevalence of CAEV in dairy goats in the Southern regions of Korea was previously investigated and determined to be $23.7 \%$ [12]. The majority of dairy goats for milk production in Korea are imported. We hypothesize that the higher frequency of CAEV in dairy goats is due to their importation from countries where CAEV is prevalent and by bulk milk feeding using infected milk. The majority of dairy goats are reared in the Southern region of Korea. This suggests that CAEV has been transmitted from imported dairy goats to Korean black goats in this region. In the present study, the prevalence of CAEV in Korean black goats was more than eight-fold lower. The CAEV prevalence in Korea that was calculated in the present study is lower than values reported in the United States [7], United Kingdom [8], Spain [5] and Brazil [2]. This may indicate that either CAEV was recently introduced into Korean black goats or those Korean
Table 1. Caprine arthritis-encephalitis virus (CAEV) serology results based on enzyme-linked immunosorbent assays (ELISA) and agar gel immunodiffusion (AGID) tests

\begin{tabular}{lccr}
\hline \multirow{2}{*}{ AGID } & \multicolumn{2}{c}{ ELISA } & \multirow{2}{*}{ Total } \\
\cline { 2 - 3 } & Positive & Negative & \\
\hline Positive & 18 & 5 & 23 \\
Negative & 17 & 618 & 635 \\
\hline Total & 35 & 623 & 658 \\
\hline
\end{tabular}

black goats are resistant to CAEV.

This is the first report of a large-scale serological survey of CAEV prevalence in the Korean goat industry. This study clearly indicates that CAEV infection originally occurred among Korean black goats. Further studies should focus on explaining the risk factors associated with CAEV prevalence in the Korean goat population in an attempt to control new infections.

ACKNOWLEDGMENT. This study was financially supported by the Animal, Plant, and Fisheries Quarantine and Inspection Agency, Ministry for Food, Agriculture, Forestry and Fisheries, Republic of Korea.

\section{REFERENCES}

1. Adams, D. S., Oliver, R. E., Ameghino, E., DeMartini, J. C., Verwoerd, D. W., Houwers, D. J., Waghela, S., Gorham, J. R., Hyllseth, B., Dawson, M., Trigo, F. J. and McGuire, T. C. 1984. Global survey of serological evidence of caprine arthritisencephalitis virus infections. Vet. Rec. 115: 493-495. [Medline] [CrossRef]

2. Bandeira, D. A., de Castro, R. S., Azevedo, E. O., de Souza Seixas Melo, L. and de Melo, C. B. 2009. Seroprevalence of caprine arthritis-encephalitis virus in goats in the Cariri region, Paraiba state, Brazil. Vet. J. 180: 399-401. [Medline] [CrossRef]

3. Blacklaws, B. A., Berriatua, E., Torsteinsdottir, S., Watt, N. J., de Andres, D., Klein, D. and Harkiss, G. D. 2004. Transmission of small ruminant lentiviruses. Vet. Microbiol. 101: 199-208. [Medline] [CrossRef]

4. Cheevers, W. P., Roberson, S., Klevjer-Anderson, P. and Crawford, T. B. 1981. Characterization of caprine arthritis-encephalitis virus: a retrovirus of goats. Arch. Virol. 67: 111-117. [Medline] [CrossRef]

5. Contreras, A., Corrales, J. C., Sanchez, A., Aduriz, J. J., Gonzalez, L. and Marco, J. 1998. Caprine arthritis-encephalitis in an indigenous Spanish breed of dairy goat. Vet. Rec. 142: 140-142. [Medline] [CrossRef]

6. Crawford, T. B., Adams, D. S., Cheevers, W. P. and Cork, L. C. 1980. Chronic arthritis in goats caused by a retrovirus. Science 207: 997-999. [Medline] [CrossRef]

7. Cutlip, R. C., Lehmkuhl, H. D., Sacks, J. M. and Weaver, A. L. 1992. Prevalence of antibody to caprine arthritis-encephalitis virus in goats in the United States. J. Am. Vet. Med. Assoc. 200: 802-805. [Medline]

8. Dawson, M. 1989. The caprine-arthritis encephalitis syndrome. Vet. Annu 29: 98-102.

9. de Andrés, D., Klein, D., Watt, N. J., Berriatua, E., Torsteinsdottir, S., Blacklaws, B. A. and Harkiss, G. D. 2005. Diagnostic tests for small ruminant lentiviruses. Vet. Microbiol. 107: 49-62. 
[Medline] [CrossRef]

10. Konishi, M., Tsuduku, S., Haritani, M., Murakami, K., Takamitsu, T., Kobayashi, C., Yoshikawa, K., Kimura, K. M. and Sentsui, H. 2004. An epidemic of caprine arthritis encephalitis in Japan: Isolation of the virus. J. Vet. Med. Sci. 66: 911-917. [Medline] [CrossRef]

11. KOSIS. Korean Statistical Information System [cited 2011 January 20]. Available from http://kosis.nso.go.kr.

12. Lim, J. S., Kim, H. J., O, H. Y., Lee, T. U. and Park, S. J. 2008. Investigation of caprine arthritis-encephalitis from dairy goat in Jeonnam province. Korean J. Vet. Serv 31: 273-281.
13. Narayan, O. and Cork, L. C. 1990. Caprine arthritis-encephalitis virus. pp. 441-452. In: Infections of Ruminants (Dinter, Z. and Morein, B. eds.), Elsevier Science Publisher B. V., Amsterdam.

14. Park, J. E., Son, S. Y. and Shin, H. J. 2010. Sequence comparison on gag gene of caprine arthritis encephalitis virus from Korea. Virus Genes 41: 99-101. [Medline] [CrossRef]

15. Reina, R., Berriatua, E., Luján, L., Juste, R., Sánchez, A., de Andrés, D. and Amorena, B. 2009. Prevention strategies against small ruminant lentiviruses: an update. Vet. J. 182: 31-37. [Medline] [CrossRef] 